\title{
The importance of the pet market for the development of new products based on medicinal plants and their derivatives
}

\author{
Douglas S. A. Chaves
}

Departamento de Ciências farmacêuticas, Universidade Federal Rural do Rio de Janeiro, Seropédica/Rio de Janeiro - Brasil. CEP 23897-000

Article history: Received 9 April 2020: Revised 26 May 2020: Accepted 29 May 2020: Published online 30 June 2020

The world pet market is currently the fastest growing in the world. The Brazilian Pet Industry Association estimates that the world pet market had a turnover of US \$ 124.6 billion in 2018, representing growth of $4.3 \%$ in relation to 2017 , when the turnover was the US $\$ 119.5$ billion. The United States is the country with the highest sales, accounting for approximately $40.2 \%$ of all world sales, followed by Brazil. China now has a share of $3.1 \%$ of the world market, while until 2016, it was not among the top 10 worldwide (Abinpet, 2020).

Figure 1 below shows the gross revenue in the percentage of the countries with the highest sales of pet products.

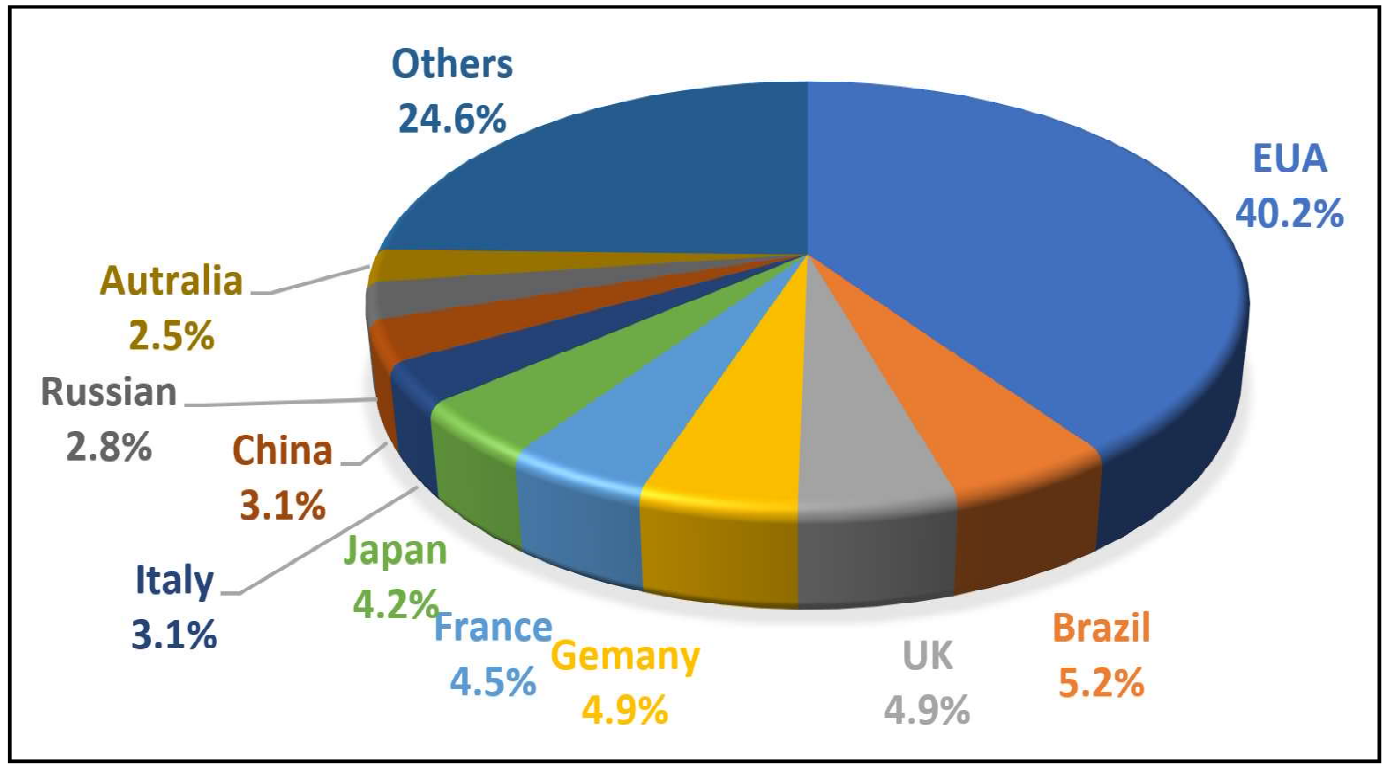

Figure 1: Ten countries with the highest turnover in the pet market, totaling \$ 124.6 billion (Abinpet, 2020).

Brazil has the second largest population of pets in the world, reaching approximately 139 million animals, with 54 million dogs, 39.8 million ornamental birds, 23.9 million cats, 19.1 million fish and 2.3 million other animals (Abinpet, 2020).

The growth of the market is accompanied by the rising concern of owners with the health of their animals, both regarding feeding and

Corresponding author: Dr. Douglas Siqueira Chaves

Professor and Research, Departamento de Ciências Farmacêuticas, Universidade Federal Rural do Rio de Janeiro, Seropédica/Rio de Janeiro - Brasil. CEP 23897-000

E-mail: gnosy.ufrrj@gmail.com; chavesdsa@ufrrj.br Tel.: +552126821763

Copyright $(9) 2020$ Ukaaz Publications. All rights reserved.

Email: ukaaz@yahoo.com; Website: www.ukaazpublications.com the use of medicines with less severe side effects, including for the prevention and treatment of infestations by parasites such as fleas and ticks, as well as with public health regarding the transmission of pathogens from animals to humans (Chomel et al., 2011).

In addition to human exposure, medicines administered to pets to control fleas and ticks can be introduced into the wastewater treatment system during the routine bathing of animals, since they are often bathed in residential bathrooms or by professional services where the waste is sent directly to the sewer system (Teerlink et al., 2017).

Fleas (Ctenocephalides felis and C. canis) and ticks (Rhipicephalus sanguineus) transmit diseases to domestic animals, requiring their 
control with chemotoxic agents. However, the agents available in the market are toxic to animals (Mello et al., 2002; Chomel et al., 2011), humans and the environment (Spadotto et al., 2006; Oliveira et al., 2001). Therefore, it is essential to search for substances from natural origins for the control of these ectoparasites, in line with the concept of Unique Health, which has emerged to convey the inseparable union between animal, human and environmental health. In this sense, looking at the whole is essential to ensure high levels of health. Many diseases can be better prevented and combated through integrated action between veterinary medicine, human medicine and other scientific fields.

Fleas and ticks can cause great discomfort to pets, as well as spreading diseases (Esccap, 2018). They can cause allergic reactions of varying intensity, due to the effect of the bite and saliva inoculation, and in large infestations they can cause iron deficiency anemia in young or small animals (Linardi et al.,2012; Esccap, 2018). Dogs and cats that are not allergic can be asymptomatic carriers, but in allergic ones, the lesions include papules, crusts, erythema and alopecia, among others (Esccap, 2018; Medleau et al., 2003). Parasitized animals, in an attempt to get rid of fleas, can bite and scratch the skin, pulling out hair and scarifying skin tissues (Linardi, 2012; Esccap, 2018).

The most widely used strategy for the control of insect populations is the administration of insecticides, substances of natural or synthetic origin used to eliminate insects at different stages of their life cycle (Correia et al., 2006; Dos Santos et al., 2020;).

There are several chemical classes available for flea control, such as pyrethroids, organophosphates, carbamates, phenylpyrazoles, nitroguanidines and macrocyclic lactones, which affect the insect's nervous system, as well as growth regulating substances (IGRs - “ insect growth regulators"), currently known as arthropod growth regulators (AGRs). These target other organs than those of the neural system, and due to their performance in specific arthropod systems, they are characterized as selective products (Scott et al., 2002; Otranto et al., 2008; Ellse et al., 2014).

Over the years, demands have increased from society for alternative pest control products that do not cause negative impacts on human and animal health, the environment and natural resources (Guimaraes et al., 2014). Although, efficient, synthetic insecticides cause a series of problems, such as environmental contamination, presence of high levels of residues in food, biological imbalance due to the elimination of natural enemies, and the emergence of resistant insect populations (Hernández et al., 1996).

Botanical insecticides are products derived from plant parts, directly through grinding into powder, or derived by extraction with water or organic solvents such as alcohol, ether, acetone, chloroform, etc., or by distillation (Machado et al., 2007). These insecticides have been suggested as potential alternatives to the use of conventional synthetic insecticides, presumably because extracts and essential oils have lesser impacts on human health and the environment (Isman et al., 2011).

The search for such alternatives is attracting rising research interest around the world. A survey carried out in the Elsevier database, covering the last ten years, revealed that studies of natural products applied to veterinary medicine have been growing steeply (Figure 2), including studies of natural products for flea and tick treatment (Figure 3).

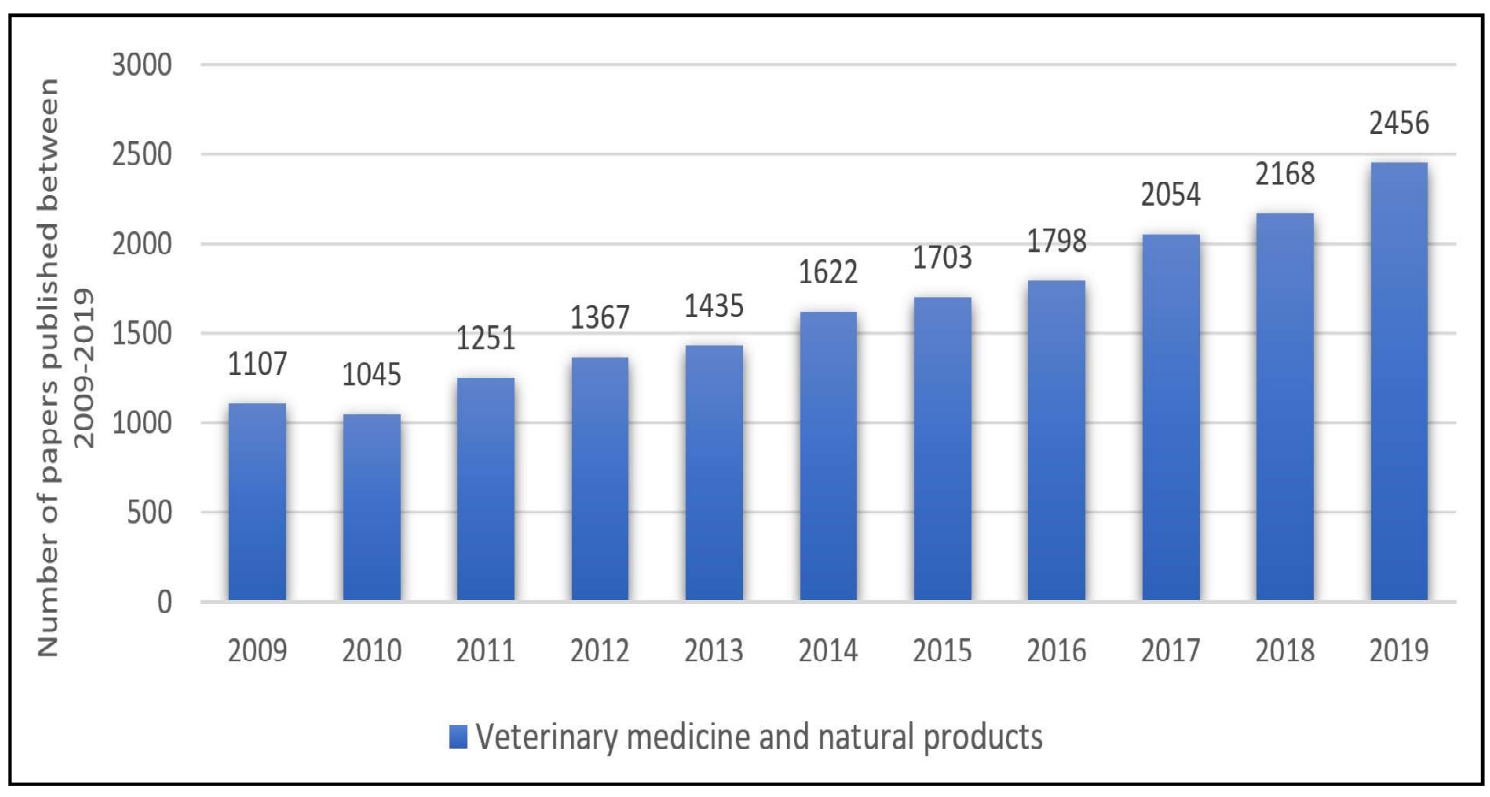

Figure 2: Number of papers published between 2009-2019; keywords veterinary medicine and natural products. Database Science Direct, 2020. 


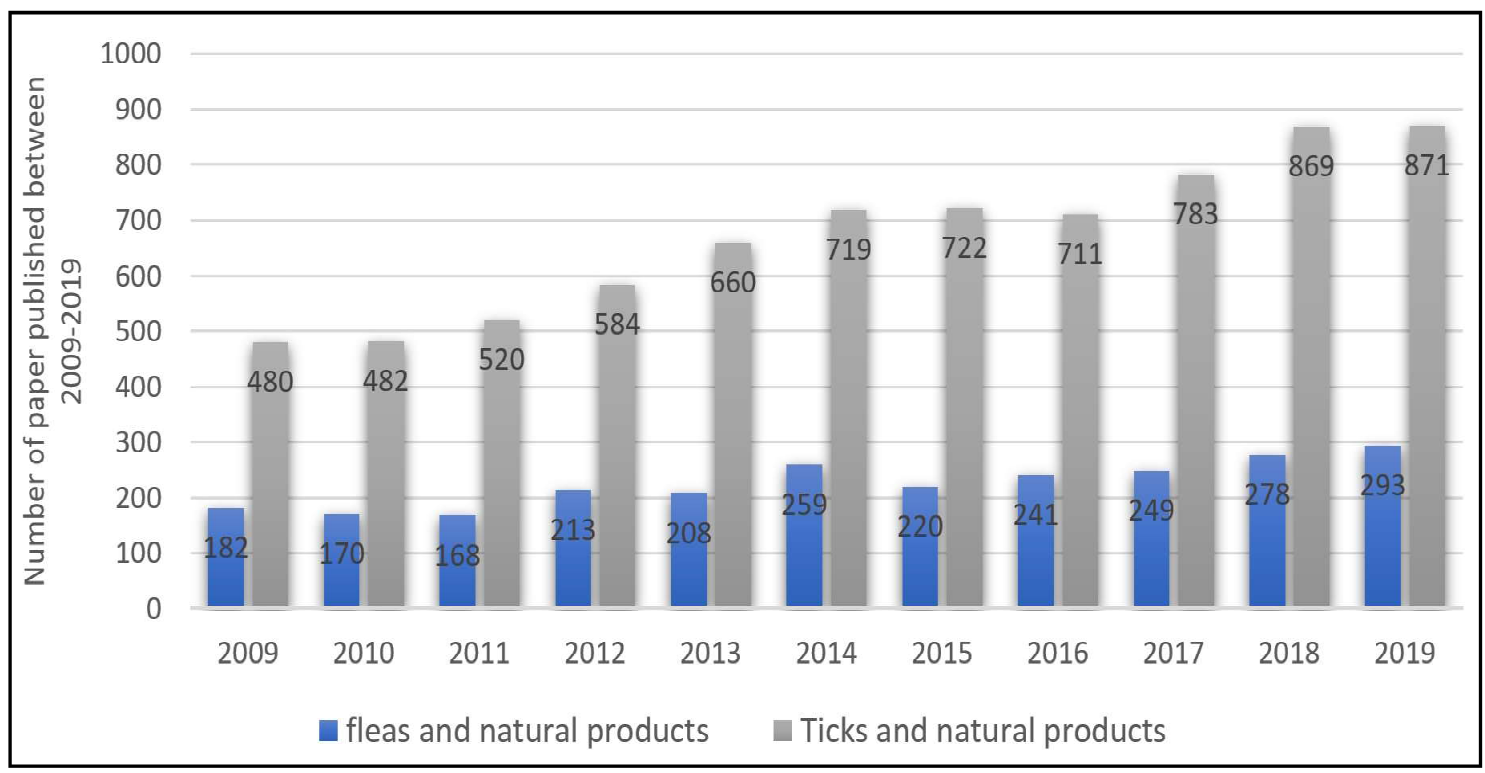

Figure 3: Number of papers published between 2009-2019; keyword's fleas and natural products, and ticks and natural products. Database Science Direct, 2020.

Examples of natural insecticides include pyrethrin (the most important group of natural insecticides), nicotine and rotenone. The known insecticides of synthetic origin belong to the group of chlorinated and phosphorous substances, carbamates, pyrethrin and synthetic pyrethroids (George et al., 2014; Ellse, 2014), among others that have appeared in recent years (Dos Santos et al., 2020).

My team has published several works involving extracts and essential oils of plant species investigating the insecticidal action of these natural products. Some results are presented below in relation to the control of these ectoparasites.

Rosmarinus officinalis L. (Lamiaceae), rosemary, is rich in flavonoids, tannins, terpenes and saponins. The crude extract obtained by maceration in methanol showed activity (95\%) in vitro at a concentration of 2,500 ppm against adult forms of Ctenocephalides felis felis. At the concentrations of 10,000 and 20,000 ppm of crude extract, we observed inhibition rates of 45 and $55 \%$, respectively, against Rhipicephalus sanguineus (Batista et al., 2013).

Pilocarpus pennatifolius Lem. (Rutaceae), jaborandi, is a species rich in alkaloids. In a study of this plant, the extract was obtained by exhaustive maceration and the chemical composition was assessed by thin-layer chromatography, followed by colorimetric assays. Dilutions of the extract were prepared in the concentration range between 625 and 20,000 ppm. The results showed that the extract of jaborandi was active in vitro in the concentration range tested against ectoparasites, with efficacy values of $35 \%$ against $C$. felis felis, $31.82 \%$ against $R$. microplus and $59.06 \%$ against $R$. sanguineus (Batista et al., 2013a).

Essential oils (EOs) are of great importance for the control of insects and mites. Some studies have reported the efficient action of these products, with high residual effect, which is desired by the herbal industry of products for the treatment of animals (George et al., 2014).

Schinus molle L. is a species that has been extensively studied due to its high yield of essential oils, allowing its action to be evaluated against ectoparasites. Batista et al. (2016) showed the effectiveness of extracts and essential oil of this species. In an in vitro assay, the non-polar ( $n$-hexane) extract showed $100 \%$ efficacy $\left(800 \mu \mathrm{g} \mathrm{cm}^{-2}\right.$; $\left.\mathrm{LD}_{50}=524 \cdot 80 \mu \mathrm{g} \mathrm{cm}^{-2}\right)$ after 24 and $48 \mathrm{~h}$. Its major compound was lupenone $(50 \cdot 25 \%)$. Essential oils from fruits and leaves were evaluated and had $100 \%$ efficacy against adult fleas at $800 \mu \mathrm{g} \mathrm{cm}^{-2}$ $\left(\mathrm{LD}_{50}=353.95 \mu \mathrm{g} \mathrm{cm}^{-2}\right)$ and at $50 \mu \mathrm{g} \mathrm{cm}^{-2}\left(\mathrm{LD}_{50}=12.02 \mu \mathrm{g} \mathrm{cm}^{-2}\right)$, respectively. However, when evaluated against flea eggs the EO from fruits and leaves was not active against. This was the first study reporting the insecticidal effects of essential oils and extracts obtained from Schinus molle against Ctenocephalides felis felis (Batista et al., 2016).

In 2019, a study involving the essential oil of the species Ocimum gratissimum L. (clove Basil) showed that the components of the oil (mainly eugenol) were active in the control of ticks. The bioassay results showed that $O$. gratissimum essential oil exhibited strong acaricidal activity against $R$. sanguineus $\left(\mathrm{LC}_{50}=6.2 \mathrm{mg} \mathrm{ml}^{-1}\right)$. These results are promising for the development of herbal products to obtain an alternative method of controlling tick larvae while minimizing the use of synthetic products (Ferreira et al., 2019).

EOs from Alpinia zerumbet (Pers.) B. L. Burtt \& R. M. Sm, Cinnamomum spp., Laurus nobilis L., Mentha spicata L., Ocimum gratissimum L. and Cymbopogon nardus (L.) Rendle were effective against immature stages and adults of $C$. felis felis. Bioassay results suggested that the method of evaluation was able to perform pre- 
screening of the activity of several EOs, including the discriminatory evaluation of flea stages by their $\mathrm{LC}_{50}$ values. Ocimum gratissimum EO was the most effective in the in vitro assays against all flea stages, presenting adulticide $\left(\mathrm{LC}_{50}=5.85 \mu \mathrm{g} \mathrm{cm}^{-2}\right)$, ovicidal $\left(\mathrm{LC}_{50}=1.79 \mu \mathrm{g}\right.$ $\left.\mathrm{cm}^{-2}\right)$ and larvicidal $\left(\mathrm{LC}_{50}=1.21 \mu \mathrm{g} \mathrm{cm}^{-2}\right)$ activities, causing mortality at low doses (dos Santos et al., 2020). Syzygium aromaticum essential oil (SAEO) and its major compound eugenol (EG), also produced excellent results against adult fleas and the maturation of eggs into adults of Ctenocephalides felis felis. Flea mortality was evaluated 24 and $48 \mathrm{~h}$ after exposure. In order to evaluate the inhibition of the maturation of eggs into adults, 10 eggs were exposed to filter paper impregnated with SAEO and EG at the same concentrations used in the pulicidal test, with evaluation performed 30 days after incubation. Untreated fleas were maintained in both studies (control group). The median lethal concentration $\left(\mathrm{LC}_{50}\right)$ values of SAEO were $5.70 \mu \mathrm{g} \mathrm{cm}^{-}$ ${ }^{2}$ in $24 \mathrm{~h}$ and $3.91 \mu \mathrm{g} \mathrm{cm}^{-2}$ in $48 \mathrm{~h}$. The $\mathrm{LC}_{90}$ values were $16.10 \mu \mathrm{g} \mathrm{cm}^{-}$ ${ }^{2}$ and $15.80 \mu \mathrm{g} \mathrm{cm}^{-2}$ in 24 and $48 \mathrm{~h}$, respectively. The $\mathrm{LC}_{50}$ values regarding the maturation of eggs into adults were $0.30 \mu \mathrm{g} \mathrm{cm}^{-2}$ and the $\mathrm{LC}_{90} 3.44 \mu \mathrm{g} \mathrm{cm}^{-2}$. The $\mathrm{LC}_{50}$ values of EG were $2.40 \mu \mathrm{g} \mathrm{cm}^{-2}$ in 24 $\mathrm{h}$ and $1.40 \mu \mathrm{g} \mathrm{cm}^{-2}$ in $48 \mathrm{~h}$, while the $\mathrm{LC}_{90}$ values were $8.10 \mu \mathrm{g} \mathrm{cm}^{-2}$ and $3.70 \mu \mathrm{g} \mathrm{cm}^{-2}$ in $24 \mathrm{~h}$ and $48 \mathrm{~h}$, respectively. The $\mathrm{LC}_{50}$ against maturation of eggs into adults was $0.10 \mu \mathrm{g} \mathrm{cm}^{-2}$ and the $\mathrm{LC}_{90}$ was $0.68 \mu \mathrm{g} \mathrm{cm}^{-2}$ (Lambert et al., 2020).

Nature can be an inexhaustible source of molecules that could act to control ectoparasites from pets. In addition to being mostly biodegradable products with low toxicity, in general, the use process has a low cost.

The phytomedicine is gaining wider acceptance and importance, because it is truly a multidisciplinary area, encompassing several disciplines. In view of the ever increasing amount of awesome research work to be carried in the development of phytomedicines and conventional medicines from plants, a matching increase in the number of good quality, reputed journals is a requirement. In this context, 'Annals of Phytomedicine: An International Journal' with a commitment to excellence in publishing cutting edge research in all areas of phytomedicine, is a welcome arrival. It is established that a large number of journals devoted to this branch of science, but only few of them publish articles from multidisciplinary areas, thus it a significant addition to the list of the wide-range periodicals on medicinal plants. It is graftying to see that "Annals of Phytomedicine" is catering to the needs of scientists from different closely related disciplines by promoting the publications on plant medicines and specially by inviting the commentaries of stake holders. No doubt, it is a challenging and a difficult job to run such a journal successfully. I am happy to note that 'Annals of Phytomedicine' is already on its way towards accomplishing its mission and reaching its zenith.

\section{Conflict of interest}

The author declared that there is no conflicts of interest in the course of conducting the research. The author has final decision regarding the manuscript and decision to submit the findings for publication.

\section{References}

Abinpet - Associação Brasileira da Indústria para Animais de Estimação. Available at: http://abinpet.org.br/mercado/[Accessed May12, 2020].

Batista, L.C.S.O.; Coelho, C.N.C.; Silva, A.F.; Cid, Y.P.; Magalhães, V.S.; Chaves, D.S.A. and Coumendouros, K. (2013). Rosmarinusofficinalis (Lamiaceae): atividade in vitro frente a ectoparasitos de importância veterinária. Revista Brasileira de Medicina Veterinária, 35(supl.2):119-125.

Batista, L.C.S.O.; Florencio, C.N.; Cid, Y.P; Magalhães, V.S.; Chaves, D.S.A. and Coumendouros, K. (2013a). Bioprospecção de extratos de jaborandi contra Ctenocephalides felis felis, Rhipicephalus sanguineus e Rhipicephalus microplus. Revista Brasileira de Medicina Veterinária, 35(supl.2):113-118.

Batista, C.S.O.; Cid, Y.P.; Almeida, A.P.; Prudêncio, E.R.; Riger, C.J.; Souza, M.A.A.; Coumendouros, K. and Chaves, D.S.A. (2016). In vitro efficacy of essential oils and extracts of Schinus molle L. against Ctenocephalides felis felis. Parasitology, 143(5):627-638.

Chomel, B. (2011). Tick-borne infections in dogs - An emerging infectious threat, Veterinary Parasitology, 179(4):294-301.

Correia, S.J.; David, J.P. and David, J.M. (2006). Metabólitos secundários de espécies de Anacardiaceae. Química Nova, 29(6):1287-1300.

Dos Santos, J.V.B.; Chaves, D.S.A.; Souza, M.A.A.; Riger, C.J.;Lambert, M.M.; Campos, D.R.; Moreira, L.O.; Siqueira, R.C.S.; Osorio, R.P.;Boylan, F.; Correa, T.R. and Couendouros, K. (2020). In vitro activity of essential oils against adultand immature stages of Ctenocephalides felisfelis. Parasitology, 147(3):340-347

Ellse, L. (2014). The use of essential oils in veterinary ectoparasite control: A review. Medical and Veterinary Entomology, 28(3):233-243.

Esccap. Guideline 03 six edition. Control of Ectoparasites in Dog and Cats. United Kingdon, 2018.

Ferreira, T.P.: Cid, Y.P.; Cardilo, M.A.; Santos, G.C.M.; Avelar, B.R.; Freitas, J.P.; Ozarowski, M.; Souza, M.A.A. and Chaves, D.S.A. (2019). Atividade acaricida in vitro do oleo essencial de Ocimum gratissimum sobre larvas de Rhipicephalus sanguineus, Amblyomma sculptum e Rhipicephalus microplus. Revista Virtual de Química, 11(5):1604-1613.

George, D.R.; Finn, R.D.; Graham, K.M. and Olivier, A.E. (2014). Present and future potential of plant-derived products to control arthropods of veterinary and medical significance. Parasites and Vectors, 7:28

Ferreira, T.P.; Cid, Y.P.; Alves, M.C.C.; Santos, G.C.M.; Avelar, B.R.;Freitas, J.P.; Ozarowski, M.; de Souza, M.A.A. and Chaves, D.S.A. (2019). In vitro acaricidal activity of Ocimum gratissimum essential oil on Rhipicephalus sanguineus, Amblyomma sculptum and Rhipicephalus microplus larvae rev. Virtual Quim., 11(5):1604-1613.

Guimarães, S.S.; Potrich, M.; Silva, E.R.L.; Wolf, J.; Pegorini, C.S. and Oliveira, T.M. Ação repelente, inseticida e fagoinibidora de extratos de pimenta dedo-de-moça sobre o gorgulho do milho. Arquivos do Instituto Biológico, 81(4):322-328.

Hernández, C.R. and Vendramim, J.D. (1996). Toxicidad de extractosacuosos de Meliaceae em Spodopterafrigiperda (Lepidoptera: Noctuidae). Manejo Integrado Plagas, pp:14-22.

Isman, M.B.; Miresmailli, S. and Machial, C. (2011). Commercial opportunities for pesticides based on plant essential oils in agriculture, industry and consumer products. Phytochemistry Review, 10:197-204.

Lambert, M.M.; Campos, D.R.; Borges, D.A; Avelar, B.R.; Ferreira, T.P.; Cid, Y.P.; Boylan, F.; Scott, F.B.; Chaves, D.S.A. and Coumendouros, K. (2020). Activity of Syzygium aromaticumessential oil and its main constituent eugenol in the inhibition of the development of Ctenocephalides felis felis and the control of adults. Veterinary Parasitology, 282:109-126. 
Limongi, J.E.; Silva, J.J.; Paula, M.B.C. and Mendes, J. (2013). Aspectos epidemiológicos das infestações por sifonápteros na área urbana do município de Uberlândia, Minas Gerais, 2007-2010. Epidemiologia e Serviços de Saúde, 22(2):285-294.

Linardi, P.M. (2004). Biologia e epidemiologia das pulgas. Revista Brasileira de Parasitologia Veterinária, 13:103-106.

Linardi, P.M. and Santos, J.L.C. (2012). Ctenocephalides felis felis vs. Ctenocephalides canis (Siphonaptera: Pulicidae): Some issues in correctly identify these species. Revista Brasileira de Parasitologia Veterinária, 21(4):345-354.

Machado, L.A.; Silva, V.B. and Oliveira, M.M. (2007). Uso de extratos vegetais no controle de pragas em horticultura. Biológico, 69(2):103-106.

Medleau, L. and Hnilica, K.A. (2003). Dermatologia De Pequenos Animais. Editora. Roca., pp:78-80/113-115.

Mello, M.O. and Silva-Filho, M.C. (2002). Plant-insect interactions: an evolutionary arms race between two distinct defense mechanisms. Brazilian Journal of Plant Physiology, 14:71-81.
Oliveira, A.R.M.F.; Jezler, C.N.; Oliveira, R.A.; Mielke, M.S. and Costa, L.C.B. (2012). Determinação do tempo de hidrodestilação e do horário de colheita no óleo essencial de menta. Horticultura Brasileira, 30:155-159.

Otranto, D. and Wall, R. (2008). New strategies for the control of arthropod vectors of disease in dogs and cats. Medical and Veterinary Entomology, 22(1):291-302.

Rust, M.K. and Dryden, M.W. (1997). The biology, ecology, and management of the cat flea. Annual Review Entomology, 42(1):451-473.

Scott, F.B.; Martins, I.V.F.; Souza, C.P. and Correia, T.R. (2002). Aspectos gerais do controle da pulga Ctenocephalides felis felis em cães. A Hora Veterinária, 21(125):13-18.

Spadotto, C.A. (2006). Avaliac'abo de Riscos Ambientais de Agrotoìxicos em Condic'opes Brasileiras. Embrapa Meio Ambiente, $1^{\text {a }}$ Edição, SãoPaulo - Brasil.

Teerlink, J.; Hernandez, J. and Budd, R. (2017). Fipronil washoff to municipal wastewater from Dogs Treated With Spot-On Products. Sci. Total Environ., pp:599-600:960-966.

Citation: Douglas S. A. Chaves (2020). The importance of the pet market for the development of new products based on medicinal plants and their derivatives. Ann. Phytomed., 9(1):1-6. http://dx.doi.org/10.21276/ap.2020.9.1.1 


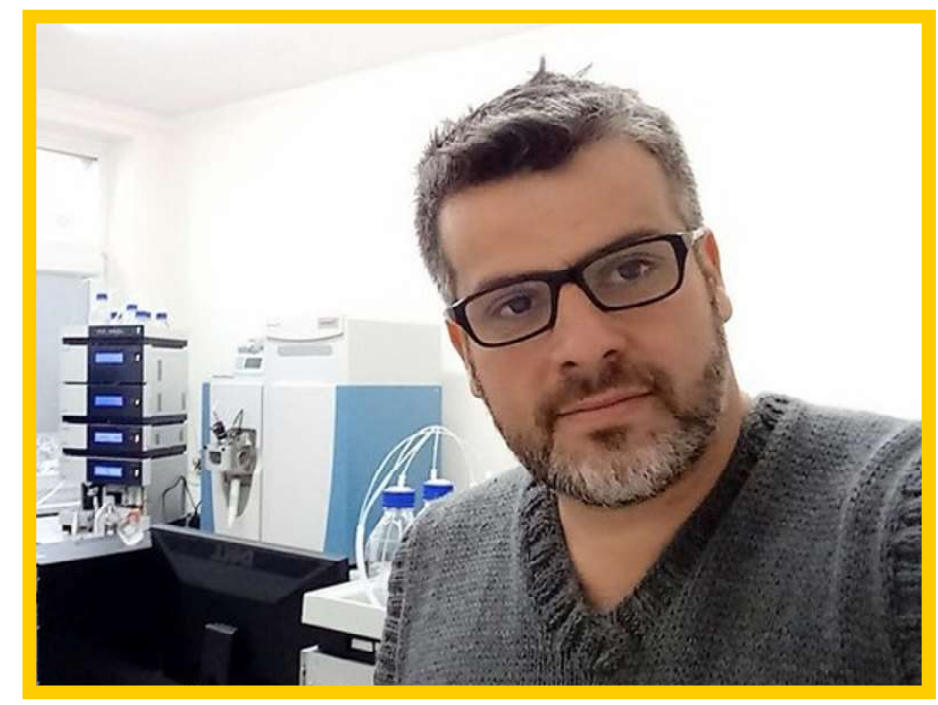

Professor Douglas S. A. Chaves

Departamento de Ciências farmacêuticas, Universidade Federal Rural do Rio de Janeiro, Seropédica/Rio de Janeiro - Brasil. CEP 23897-000

\section{Biography}

Professor Douglas Siqueira de Almeida Chaves was born in 1981 Mendes, Rio de Janeiro. He Graduated in Pharmacy, master's and doctorate in Chemistry of Natural Products from the Federal University of Rio de Janeiro. Professor Chaves is Associate Professor of Pharmacognosy, Department of Pharmaceutical Sciences, Federal Rural University of Rio de Janeiro/Brazil (UFRRJ). Experience in the Pharmacy area, with emphasis on Chemistry of natural products, acting mainly on the following topics: pharmacognosy, herbal medicines, analytical methods, organic chemistry, chemistry of natural products, phytochemistry, development of products aimed at animal and human health. Professor Chaves has a 15 years' background of teaching and research activities in Pharmacognosy, phytotherapy, development of new phytotherapy and natural products with veterinary importance. He has more than fifty papers in journals of high impact and some chapters of book; associate editor of three journal and referee of several journals such as Industrial Crops and Products, Brazilian Journal of Pharmacognosy, Natural Products Research and others. Professor Chaves published several papers about the chemical composition of essential oil and their activity against insect of veterinary importance. He has some presentations as invited and plenary speaker and has collaboration with research of various countries (Portugal, Poland, Mexico, India, Hungary and Italy). Paper presentation: He has presented more than 70 research papers in various National and International seminars, conferences and symposiums and organized workshops and conferences. Professor of the Pos-graduate Program in Chemistry (PPGQ) and Pos-graduate Program in Veterinary Sciences (PPGCV) at UFRRJ. Currently, Southeast Regional Coordinator of the Brazilian Society of Pharmacognosy and Industrial scientific and technological development fellow of the Special Cooperation Program with the Ministry of Health - COSA. Member of the American Society of Pharmacognosy, Member of the Brazilian Society of Pharmacognosy and Member of the Polish Herbal Committee. Actually, is Head of the Department of Pharmaceutical Sciences. Professor Chaves is working actually in three important projects: Development of phytotherapy from medicinal Cannabis; Herbo Chain: development of an antiviral based in green propolis against SARS-CoV-2; Development of new phytotherapy from Momordica charantia. 